A farming crisis or a tourism disaster?

An analysis of the foot and mouth disease in the UK

Dr Graham A. Miller

Senior Lecturer

Centre for Tourism

University of Westminster

Tel: +44 2079115000 ext 3054

Fax: +44 2079115171

Email: G.Miller01@wmin.ac.uk

Dr Brent W. Ritchie

School of Service Management

University of Brighton

49 Darley Road

Eastbourne

BN20 7UR

Tel: +44 1273643634

Fax: +44 1273643619

Email: b.ritchie@bton.ac.uk

and

Tourism Program

University of Canberra

ACT 2601

Australia 


\title{
A farming crisis or a tourism disaster? An analysis of the foot and mouth disease in the UK
}

\begin{abstract}
As the number of disasters and crises affecting the tourism industry increases, it is becoming necessary to understand the nature of these disasters and how to manage and limit the impacts of such incidents. This paper defines crises and disasters before discussing the area of crisis and disaster management. The paper then applies the foot and mouth outbreak which occurred in the United Kingdom to the tourism disaster framework proposed by Faulkner (2001). The paper notes that although the outbreak fits the basic principles of Faulkner's (2001) model the size, scope, and subsequent management of the outbreak over an extended period suggests that although the model is useful, it has limited usefulness because not all disasters and crises are the same. Nevertheless, by examining how crises and disasters are managed, lessons for destinations and organisations may help turn such incidents into positive forces for change and help to reduce the severity of future disasters.
\end{abstract}

Keywords: Tourism, Disaster, Crisis, Event, United Kingdom

\section{Introduction}

In February 2001, the first case of Foot and Mouth Disease (FMD) was confirmed in the UK since an outbreak of the disease in 1967. A total of 2030 cases of the disease were identified and a total of over 4 million animals were culled during the crisis with worldwide media broadcasts showing burning carcasses of culled animals. The English Tourism Council (ETC) have predicted that losses to English tourism in 2001 would be $£ 5$ bn, while in 2002 and 2003 reductions would total $£ 2.5$ bn and $£ 1$ bn respectively (ETC, 2001a). On January $15^{\text {th }} 2002$ government officials announced 
that the disease had finally been defeated after 11 months of battling the outbreak. Despite the end of the disease, the outbreak has deeply affected the farming and tourism industry and raised questions concerning government policy toward both the farming and tourism industry. Although the outbreak was not expected, questions have been specifically raised concerning the responsiveness and preparedness of the entire UK tourism industry for the falling numbers that resulted from FMD. Faulkner (2001) notes there are an increasing number of disasters and crises which affect the tourism industry, ranging from natural to human influenced disasters. This has been made most evident since the events of September $11^{\text {th }} 2001$, which has dramatically impacted upon the tourism industry illustrating the need to understand and effectively manage such incidents.

Faulkner (2001) argues that there is a lack of research on disaster phenomena in the tourism industry, on the impacts of such events on both the industry and specific organisations, and the responses of the tourism industry to disasters. Yet Lee and Harrald (1999:184) note that crisis management, disaster recovery, and organisational continuity are important competencies for managers in both the public and private sector. This paper aims to address these deficiencies as well as to consider FMD in the light of the framework for analysing and understanding tourism disasters developed by Faulkner (2001). More specifically the paper examines the framework's applicability to the foot and mouth outbreak at a national level before examining the response of an individual organisation (the Cheltenham Horseracing Association) who manage an annual sporting event, the Cheltenham Festival. The Cheltenham Festival was chosen for analysis because the town of Cheltenham is indicative of the move towards an economy dominated by tourism in a rural area 
traditionally dominated by farming. Thus, although Cheltenham and its surrounding area did not suffer the highest incidence of FMD, the economy of Cheltenham had come to be highly reliant on the tourism industry (and events in particular) and thus placed itself in a position vulnerable to disasters.

An examination of the management of the outbreak may provide assistance to other destinations and organisations in developing crisis management strategies to deal with unforeseen events such as disasters and crises. First some discussion of crisis management definitions and crisis management theory is required.

\section{Crisis and Disaster Definitions}

A number of authors have attempted to define a crisis to help improve their understanding of this phenomenon. Pauchant and Mitroff (1992:15) believe that a crisis is a "disruption that physically affects a system as a whole and threatens its basic assumptions, its subjective sense of self, its existential core." Selbst (1978 in Faulkner 2001:136) defines a crisis as "any action or failure to act that interferes with an organisation's ongoing functions, the acceptable attainment of its objectives, its viability or survival, or that has a detrimental personal effect as perceived by the majority of its employees, clients or constituents." Faulkner (2001) considers the principal distinction between what can be termed a "crisis" and a "disaster" to be the extent to which the situation is attributable to the organisation itself, or can be described as originating outside the organisation. Thus, a "crisis" describes a situation "where the root cause of an event is, to some extent, self-inflicted through such problems as inept management structures and practices or a failure to adapt to change", while a "disaster can be defined as "where an enterprise...is confronted with 
sudden unpredictable catastrophic changes over which it has little control" (Faulkner 2001:136). This enables the production of a simple matrix (see figure 1).

Figure 1: Conceptualising Crises and Disasters

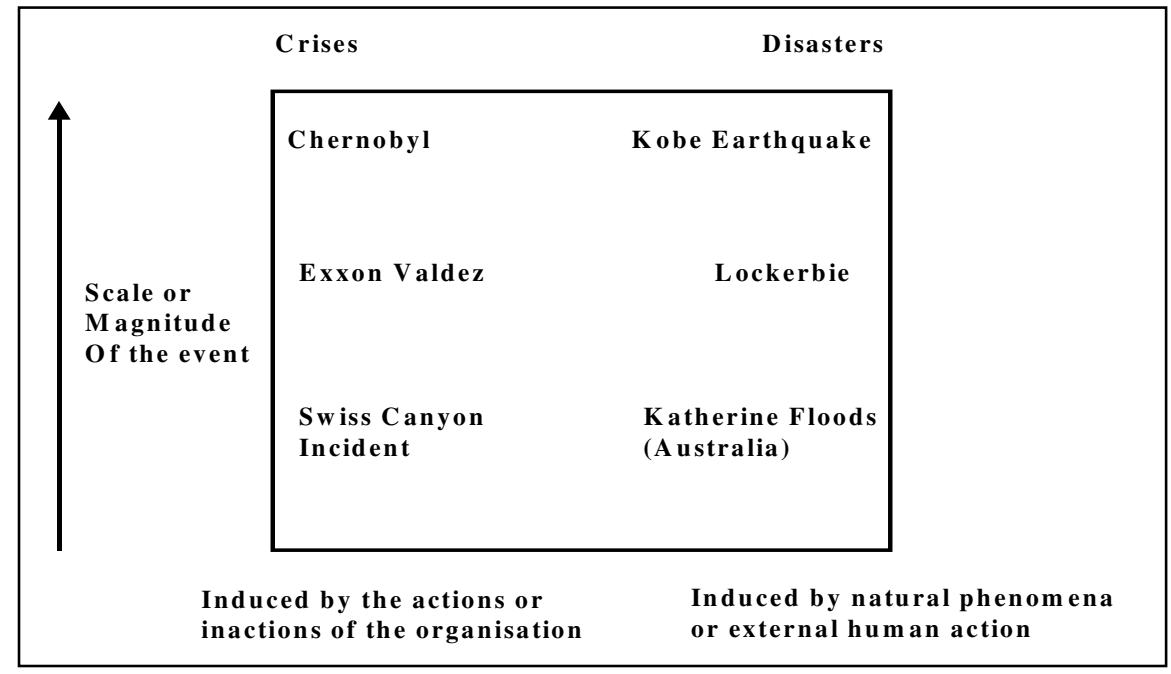

Source: Faulkner (2001)

The implication of whether a situation can be described as a crisis or a disaster is crucial in designing response options and also the ability to reflect on the situation and make changes subsequent to the negative events. A crisis implies the need for change to prevent the situation occurring again, while a disaster requires responses to limit the impacts should there be a repeat occurrence. However, FMD can be considered as both a disaster and a crisis depending on the perspective taken. Therefore, while the precise causes of FMD are a source of much disagreement, factors such as lax import regulations, a (general, though not exclusive) resistance to vaccination and a collapsing market are suggested as potential causes that designate FMD as a farming crisis. Yet, as none of the factors instrumental in the outbreak of FMD could be influenced by the tourism industry, FMD was a disaster that threatened an industry worth $£ 52.2$ bn per year to the UK economy (4\% of GDP, the UK's fifth biggest industry) and employs 1.7 million people. A total of 150,000 jobs were thought to be 
directly at risk and 3,000 small rural tourism business faced the threat of failure (ETC, 2001a). The classification of FMD is made more complex by understanding the diversification in recent years by farmers towards tourism as a way of regulating farming incomes that have fallen by $75 \%$ over the last three years to their lowest levels since the 1930s (Cook, 1999). Thus, a farmer diversified into tourism can be both cause and effect, the precipitator of crisis and a victim of disaster. The difficulty of this position is enunciated in a later section, which explores recovery options from the disease.

\section{Crisis Management}

Lee and Harrald (1999:184) state that "natural disasters can disrupt the supply and distribution chains for even the best prepared businesses... service businesses are increasingly vulnerable to electrical, communication and other critical infrastructure failures." Kash and Darling (1998:179) agree, and claim that it is no longer a case 'if' a business will face a crisis; it is rather a question of 'when', 'what type' and 'how prepared' the company is to deal with it. Both statements illustrate that although organisations are able to design pre-crisis strategies to help with crisis management they are often unable to prevent a crisis from occurring. However, the real challenge is not to recognise crises, but to recognise them in a timely fashion (Darling et al., 1996). Authors such as Burnett (1998) and Kash and Darling (1998) note that decisions undertaken before a crisis occurs will enable more effective management of the crisis, rather than organisations being managed by the crisis itself. Proactive planning through the use of strategic planning for crises will help reduce risk, time wastage, poor resource management and reduce the impacts of those that do arise (Heath, 1998). 
Furthermore, Heath (1998:9) noted "the ability of a crisis to cause other crisis situations is termed the ripple effect because these crises seem to fan outward." Heath (1998) believed that effective and well planned crisis management strategies were needed to prevent or limit the 'ripple effect' or chaos associated with crisis incidents. In other words, crisis management is crucial not only for scoping potential crises but also for limiting their impacts on other organisations, destinations or specific industry sectors.

The literature generally has discussed the nature of crises and disasters and/or discussed crisis management strategies for dealing more effectively with these instances. According to Coombs (1999) a list can be developed to illustrate possible types of crises individual organisations may face and the nature of these crises (see table 1). 
Table 1: Typology of crises and their characteristics

\begin{tabular}{|c|c|}
\hline Type of crises & Characteristics \\
\hline Natural Disasters & $\begin{array}{l}\text {-When an organisation is damaged as a result of the weather or 'acts } \\
\text { of God.' Examples include earthquakes, tornadoes, floods, hurricanes, } \\
\text { and bad storms. }\end{array}$ \\
\hline Malevolence & $\begin{array}{l}\text {-When some outside actor or opponent employs extreme tactics to } \\
\text { express anger toward the organisation or to force the organisation to } \\
\text { change. Examples include product tampering, kidnapping, terrorism } \\
\text { and espionage. }\end{array}$ \\
\hline Human Breakdowns & $\begin{array}{l}\text {-When human error causes disruptions. Examples include industrial } \\
\text { accidents and product recalls. }\end{array}$ \\
\hline Challenges & $\begin{array}{l}\text {-When the organisation is confronted by discontented stakeholders. } \\
\text { The stakeholders challenge the organisation because they believe it is } \\
\text { operating in an appropriate manner and does not meet their } \\
\text { expectations. Examples include boycotts, strikes, lawsuits, } \\
\text { government penalties and protests. }\end{array}$ \\
\hline Megadamage & $\begin{array}{l}\text {-When an accident causes significant environmental damage. } \\
\text { Examples include oil spills and radioactive contamination. }\end{array}$ \\
\hline Organisational Misdeeds & $\begin{array}{l}\text {-When management takes actions it knows will harm or serve to } \\
\text { discredit or disgrace the organisation in some way. Examples include } \\
\text { favouring short-term economic gain over social values, deliberate } \\
\text { deception of stakeholders and illegal acts by management. }\end{array}$ \\
\hline Workplace Violence & $\begin{array}{l}\text {-When an employee or former employee commits violence against } \\
\text { other employees on organisational grounds. Examples include killing } \\
\text { or injuring co-workers. }\end{array}$ \\
\hline Rumours & $\begin{array}{l}\text {-When false information is spread about an organisation or its } \\
\text { products. The false information hurts the organisation's reputation by } \\
\text { putting the organisation in an unfavourable light. Examples include } \\
\text { rumours linking the organisation to radical groups or stories that their } \\
\text { products are contaminated. }\end{array}$ \\
\hline
\end{tabular}

Source: Modified after Coombs (1999:61-62).

Although typologies are useful for beginning to understand the nature of crises, the very nature of crises makes it difficult to fully understand them. Coombs (1999) notes, all crises are different and crisis managers need to tailor responses to individual crises rather than try to plan for every individual situation. Heath (1998:272) agrees and states that "no crisis has exactly the same form, the same time limitations, the same demand for resources...or the same temporal, social and economic threats." This indicates the difficulty in developing typologies and theories to understand crisis management and how to prevent or limit the effects of crises. Authors such as Kash and Darling (1998) believe that although crises management is a requirement for all 
organisations and that business leaders recognise the concept of crisis management, many do not undertake productive steps to address crisis situations.

Other crisis management research has focussed on the stages of crises to assist in understanding crisis phenomenon and assist in proactive and strategic management of crises (see Richardson, 1994; 1995). Fink (1986) and Roberts (1994) both developed slightly different models to explain the lifecycle of crises (see table 2). Fink's (1986) model suggested a four phase anatomy of a crisis outlined in figure 2, but also noted that due to the nature of crises 'chaos' may be a more accurate depiction of a crisis from an individual perspective (see figure 3).

Figure 2: What One Crisis Cycle May Look Like

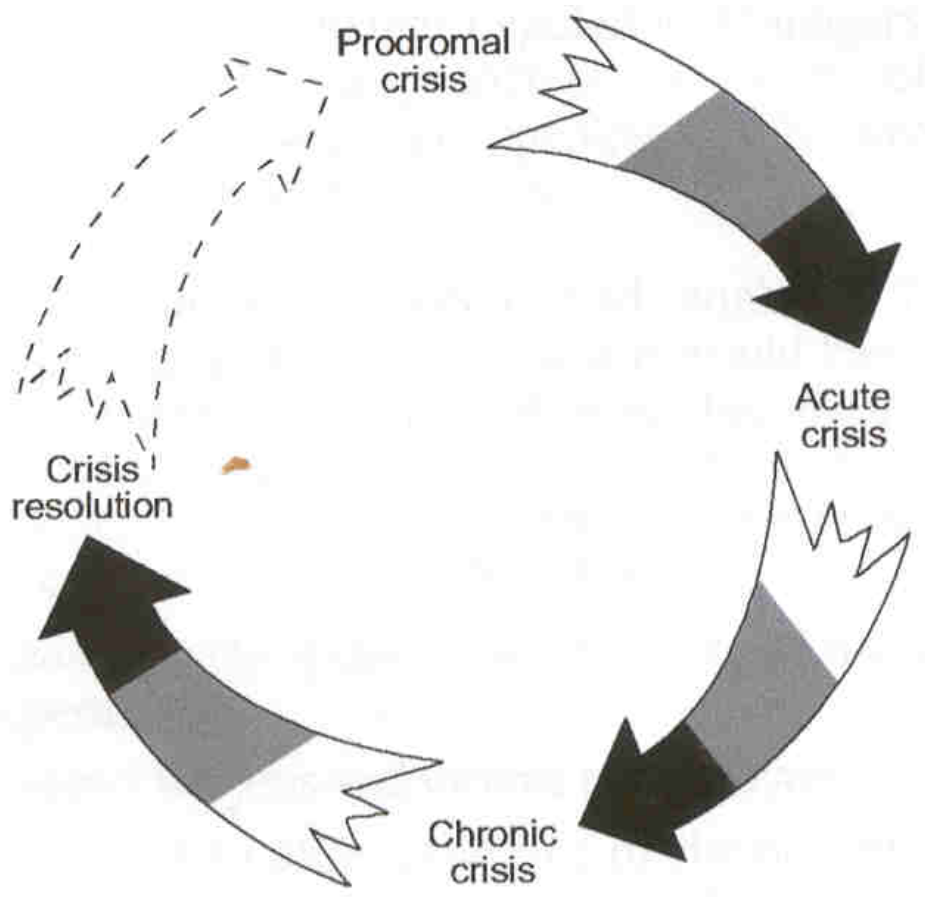

Source: Fink (1986) 


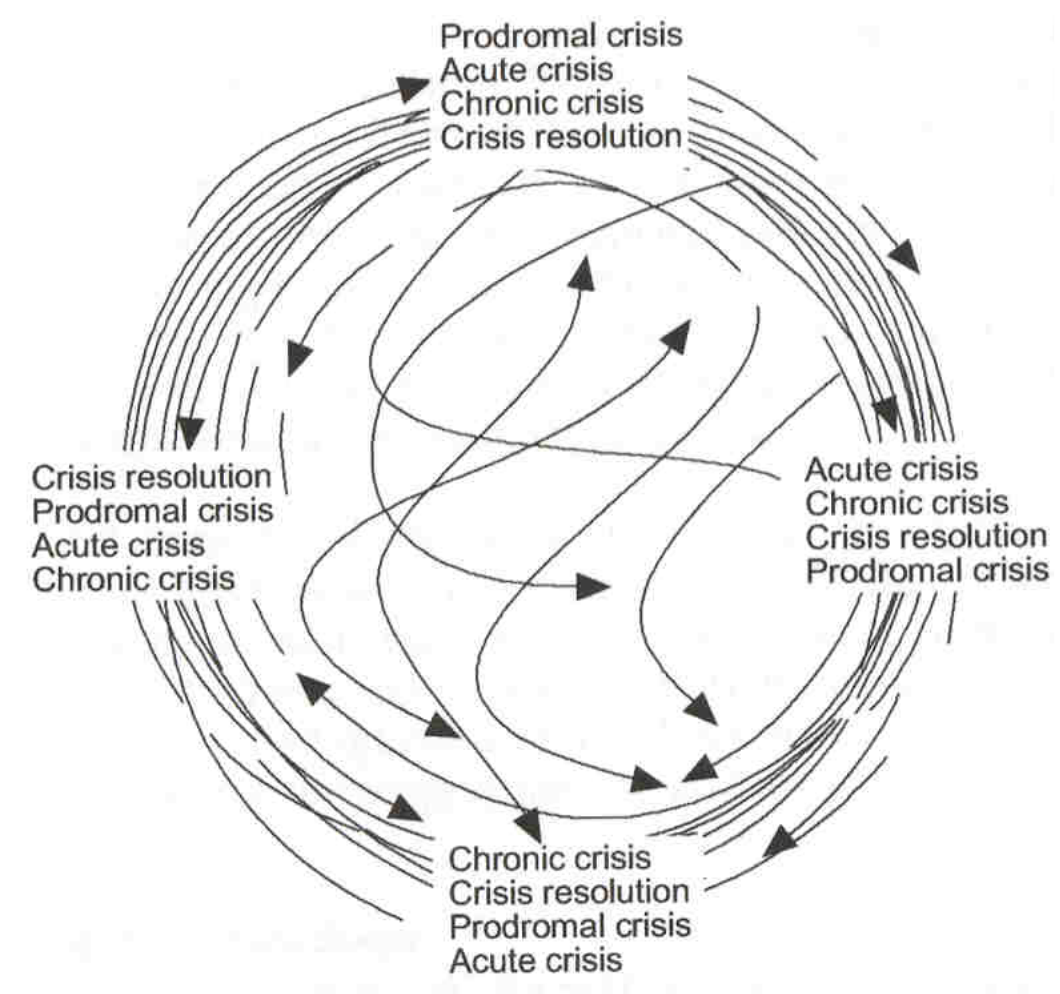

Source: Fink (1986)

From the work of Fink (1986) and Roberts (1994) Faulkner (2001) developed the first tourism specific disaster management framework and subsequently applied this framework to the Katherine Floods in Australia (see Faulkner \& Vikulov, 2001). Table 2 outlines the basis to the framework that Faulkner (2001) developed which will be applied, later in this paper, to the FMD in the UK and the response of the tourism industry and the Chelteham Horseracing Association. 
Table 2: The crisis and disaster lifecycle

\begin{tabular}{|c|c|c|}
\hline Faulkner's (2001) stages & Fink's (1986) stages & Robert's (1994) stages \\
\hline 1. Pre-event & & $\begin{array}{l}\text { Pre-event: where action can } \\
\text { be taken to prevent disasters } \\
\text { (e.g. growth management } \\
\text { planning or plans aimed at } \\
\text { mitigating the effects of } \\
\text { potential disasters) }\end{array}$ \\
\hline 2. Prodromal & $\begin{array}{l}\text { Prodromal stage: when it } \\
\text { becomes apparent that the } \\
\text { crisis is inevitable }\end{array}$ & \\
\hline 3. Emergency & $\begin{array}{l}\text { Acute stage: the point of no } \\
\text { return when the crisis has } \\
\text { hit and damage limitation is } \\
\text { the main objective }\end{array}$ & $\begin{array}{l}\text { Emergency phase: when the } \\
\text { effects of the disaster has } \\
\text { been felt and action has to } \\
\text { be taken to rescue people } \\
\text { and property }\end{array}$ \\
\hline 4. Intermediate & & $\begin{array}{l}\text { Intermediate phase: when } \\
\text { the short-term needs of the } \\
\text { people must be dealt with - } \\
\text { restoring utilities and } \\
\text { essential services. The } \\
\text { objective at this point being } \\
\text { to restore the community to } \\
\text { normality as quickly as } \\
\text { possible }\end{array}$ \\
\hline 5. Long term (recovery) & $\begin{array}{l}\text { Chronic stage: clean-up, } \\
\text { post-mortem, self-analysis } \\
\text { and healing }\end{array}$ & $\begin{array}{l}\text { Long-term phase: } \\
\text { continuation of the previous } \\
\text { phase, but items that could } \\
\text { not be addressed quickly are } \\
\text { attended to at this point } \\
\text { (repair of damaged } \\
\text { infrastructure, correcting } \\
\text { environmental problems, } \\
\text { counselling victims, } \\
\text { reinvestment strategies, } \\
\text { debriefings to provide input } \\
\text { to revisions of disaster } \\
\text { strategies) }\end{array}$ \\
\hline 6. Resolution & $\begin{array}{l}\text { Resolution: routine restored } \\
\text { or new improved state }\end{array}$ & \\
\hline
\end{tabular}

Source: After Faulkner (2001:140).

Although understanding the type of crisis and the stages of a crisis are important, understanding how to manage crises is critical. Heath (1998) identified two major approaches concerning the management of crises: the traditional crisis management approach and the risk management approach. The traditional crisis management approach involves no initial (pre-crisis) planning or management as the approach begins when the crisis starts (see figure 4). The approach of the risk management approach is to respond to the crisis and manage the impacts effectively and efficiently. 
The evaluation, risk assessment and crisis planning does not occur until after the crisis event (post-crisis) and the findings are then kept for future reference.

Figure 4: A Traditional Approach to a Crisis

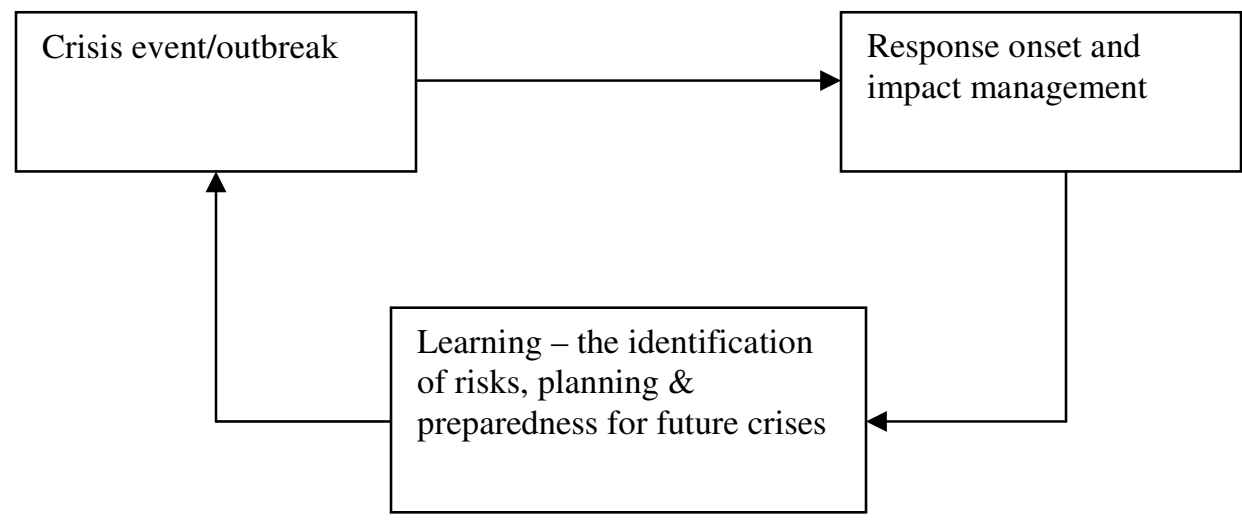

Source: Heath (1998).

The risk management approach follows on from the traditional crisis management approach as it starts where the other finishes and is concerned with assessing and managing risk before a crisis begins (pre-crisis). It is then in the position to implement appropriate response and recovery plans as the crisis emerges (see figure 5). Again, similar to the first approach, learning and feedback are crucial requirements for the development of future crisis management planning.

Figure 5: A Risk Management Approach to a Crisis

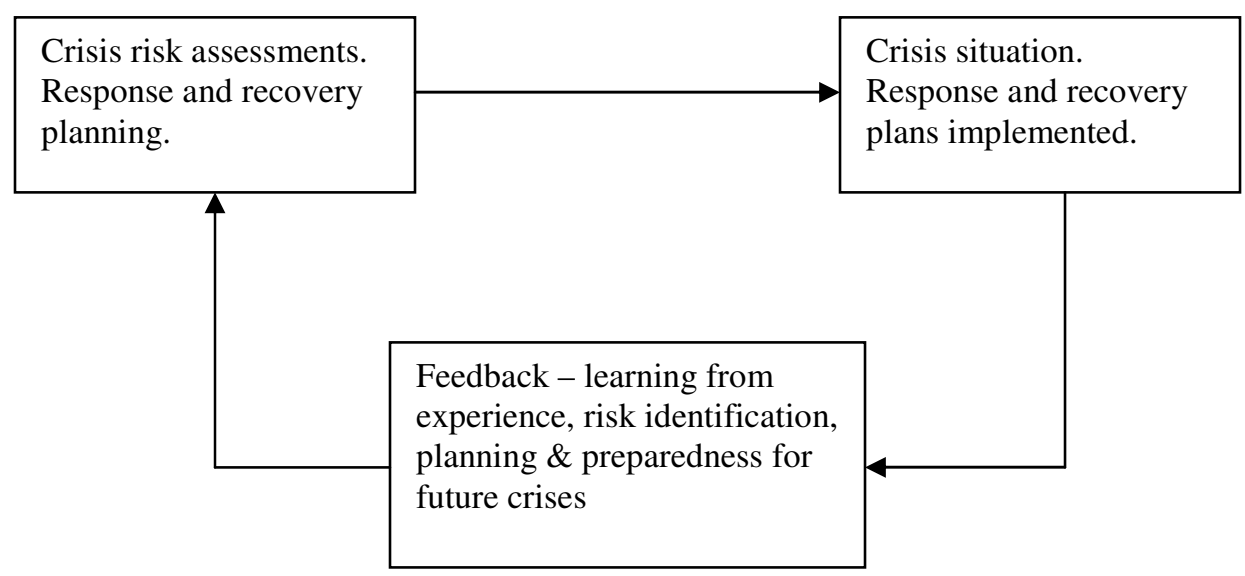

Source: Heath (1998). 
With the previous crisis management and tourism disaster management theory in mind, the authors undertook research to examine the FMD in the UK and assess the response of both the tourism industry generally, and the response of an organisation, the Cheltenham Horseracing Association. Secondary research was undertaken by examining newspaper articles throughout the duration of the foot and mouth outbreak. However, particular emphasis was placed on the analysis of 'broadsheet' newspapers from the beginning of the outbreak in February 2001 until September 2001 when the number of outbreaks was reduced to a very small number. Analysis was undertaken through examining the content of messages within the newspaper articles and the reporting angle of the newspaper media. The four main broadsheet newspapers cross the political spectrum, and thus the authors were vigilant for political bias being introduced into the research. Other secondary documents such as British Tourist Authority briefing papers and media releases by the tourism industry and English Tourism Council were also examined and analysed looking for themes and recurrent issues.

Primary research was carried out through a semi-structured in depth interview format with the Managing Director of the Cheltenham Horseracing Association (Edward Gillespie). The interview with Gillespie lasted over 2 hours and was tape recorded and transcribed. The data gathered from both the secondary and primary collection stages was analysed and an attempt was made to place key themes and issues within Faulkner's (2001) tourism disaster management framework. 
By examining the responses of the tourism industry and critically evaluating the FMD insights may be gained to assist with future crisis management in the UK and overseas. Furthermore, the paper will consider FMD in the light of the framework for analysing tourism disasters developed by Faulkner (2001) and critique the applicability of this framework for understanding the FMD. However, first background on the Cheltenham Horseracing Association is presented to set the context for subsequent sections of the paper.

\section{Cheltenham and the Cheltenham Horseracing Association}

Cheltenham is the principle town within the county of Gloucestershire, which is a rural county with a population of less than 500,000 but within easy access of the major cities of Birmingham and Cardiff, and all the permanent attractions consistent with the second city of England and the capital of Wales. Cheltenham has therefore sought to develop a plethora of festivals to promote tourism. These festivals include the International Festival of Music, the Festival of Literature, Jazz Festival, Cricket Festival and an arts festival. In 1999, over six million visitors were attracted to Cheltenham, contributing $£ 220$ million to the town’s economy and helping to support over 6,000 jobs (Cheltenham Borough Council 2002). For the county of Gloucestershire as a whole, 27 million visitors were recorded, contributing $£ 500$ million and supporting a direct workforce of 18,612 , the fourth largest employer in the county and responsible for one in ten jobs in Gloucestershire (Gloucestershire Tourism 2002). Visitors to Cheltenham therefore generate nearly half the tourism revenue for the county and the Cheltenham Festival is the largest single contributor to tourism in Cheltenham, demonstrating the prominent role that the three-day Festival has in the local economy. 
During the winter season, 10,000 of the 250,000 attendees to races stay overnight in Gloucestershire, while for the Festival, 10,000 of the 60,000 daily customers and staff remain overnight, making available accommodation extremely difficult to find during the Festival. A fully booked accommodation stock for the 3-day Festival would contribute around $£ 1.5$ million to the Cheltenham economy, gate receipts are equal to approximately $£ 4.5$ million and a conservative estimate of spending at $£ 75$ per person per visit would give a total direct contribution to the local economy of over $£ 17$ million. No formal attempt has been made to measure the benefits enjoyed by the town or the county as a result of the Festival, although it is felt that the expansion of the November meetings and the addition of Sunday racing to the schedule has encouraged racegoers to stay overnight and further explore the county.

The main activity of the Cheltenham Horseracing Association is the hosting of an annual horseracing festival called the Cheltenham Festival. The Festival is second only in the UK to the Grand National in the national hunt racing calendar, and lists itself as one of the top ten sporting events in the UK. The racecourse, in a rural part of the west of England, contains the biggest corporate entertainment area for any British sporting event. The Festival has been organised in its current format since 1948 and today is held over three days in March and comprises twenty races with prize money of over $£ 1 \mathrm{~m}$. The largest race is the Gold Cup, which takes place on the final day of the Festival and attracts prize money of $£ 290,000$. Each day of the Festival draws capacity crowds of 50,000 - with the day of the Gold Cup being sold out several months in advance. In 2000, Cheltenham was named the racecourse of the year for the seventh time in eight years by the Racegoers Club. 
Cheltenham employs 50 staff on a permanent basis, but this number will increase to over 1000 on a normal race day and in excess of 5000 per day for the Festival. Figures show Cheltenham racecourse has a turnover of $£ 12 \mathrm{~m}$, which includes $£ 11.5 \mathrm{~m}$ from racing and $£ 0.5 \mathrm{~m}$ from non-racing events. Of the $£ 11.5 \mathrm{~m}$ from racing, $£ 9 \mathrm{~m}$ (75\% of total turnover) is derived from the 3 day festival in March. From all racing throughout the year, approximately $£ 6 \mathrm{~m}$ (over $50 \%$ of total turnover) comes from the cost of admission to the races. Such ratios signal high reliance on racing for income, high reliance on the Festival for racing income, high reliance on admissions during the Festival and ultimately high reliance on corporate customers (where hospitality is included in the admission prices) during the Festival. The vast majority of these tickets are advanced sales. Media revenues contribute around $£ 1 \mathrm{~m}$ to turnover $(1.3 \mathrm{~m}$ viewers are recorded as watching the Gold Cup live on TV) and the 6500 members are worth about $£ 1.2 \mathrm{~m}$ through their membership fees. Corporate hospitality and the hire of boxes also add a further $£ 1.2 \mathrm{~m}$ to the racing turnover.

The outbreak of FMD in February 2001 led to an original intention to proceed with the Festival, as there were no confirmed cases near the racecourse. Yet the need to comply with guidelines issued by the racing industry's board of control about FMD meant rescheduling the Festival to take the place of a smaller meeting planned for April. The veterinary advice received by Cheltenham was that the Festival would pose no greater risk than a Premiership football match, none of which were cancelled. This advice was strongly contested by the local farming community, who were vocally opposed to the original intended position to continue with the Festival, instead wanting to limit as far as possible the number of people visiting the area and therein 
increasing the risk of spreading the disease (Gillespie 2001). The nature of the Hunt racing season meant that dates not conflicting with other courses were scarce and that the ground would not be suitable for hunt racing once into May. In operational terms, May also carries a heavier number of other sporting fixtures and so reduces the availability of the required plant, equipment and staff.

A further issue was the importance of the Irish racers and horses, the Irish government stated that 30 days must elapse after the final outbreak of the disease in the UK before racing could resume in Ireland. Races in Ireland form an important element of the preparation for the Festival and thus FMD served to further disjoint the season. However a subsequent confirmation of the disease at a farm close to the racecourse meant the abandonment of racing in April and the possibility of simply postponing the Festival to a later date. The Festival was thus cancelled for 2001.

\section{Tourism Disaster Management Framework}

Faulkner's (2001) uses models by Fink (1986) and Roberts (1994) to identify six phases in the process of a tourism disaster. Each phase will be considered in turn to analyse FMD and its effects on the tourism industry and the Cheltenham Horseracing Association and the Cheltenham Festival.

\section{Pre-event stage}

This period represents a time when action can be taken to prevent or mitigate the effects of the potential disaster. In 1967 there was an outbreak of FMD in the UK, which led to the cancellation of the Grand National, the largest, richest and most 
prestigious race of the national hunt season. However, the effect of thirty four years on the industry seems to have removed the benefit of experience and been replaced by a belief that a repetition of the disaster was too unlikely to prepare for. The Northumberland report into the 1967 outbreak made many conclusions that were overlooked in 2001, but the rural environment was very different then to the context of the most recent outbreak of the disease. One of the largest differences is a declining agricultural production and a downturn in agricultural activities, which has not only impacted upon the local economy of countries but society in general. Furthermore, rural or regional areas have been the regions most vulnerable to this type of agricultural decline and restructuring. As a response to a downturn in agricultural activities in rural regions the government have been promoting new economic activities, including tourism. Thus, despite the previous outbreak of the disease, the growth of tourism and its increasing dominance in rural economies has transformed the impacts that could be expected from FMD, making FMD almost a new disaster. The recency of the growth in the number of tourism businesses and the ascendancy of the tourism industry in rural economies may provide some explanation for the lack of preparedness.

Fink (1986) believes that all businesses are "on the edge of chaos" and as such should be prepared for uncertainty in order to achieve a greater sense of control. However, the effect of being struck by a disaster is that events are definitionally beyond the control of the organisation, or destination. This may produce a fatalism that as events are external to the organisation there is little that can be done to prevent them and in fact often little is done. According to Kash and Darling (1998:183) "refusing to acknowledge a crisis situation is the worst course of action to take." While refusing 
to acknowledge incidents may be akin to the ostrich sticking its head in the sand, the cost of insuring against remote events provides a further incentive to simply hope for events not to repeat themselves. Cheltenham racecourse was insured for financial loss incurred by the cancellation of the Festival, and so exhibited a rare sense of cautiousness. However, the UK has approximately 120,000 tourism business, $77 \%$ of which have a turnover of less than $£ 250,000$ per annum (ETC, 2001a). The small size of the individual businesses in a fragmented industry meant that for many of these smaller businesses, the losses caused by FMD were uninsured and the lessons from 1967 unlearnt.

\section{Prodromal}

This phase refers to when it is apparent that a disaster is imminent, but has not yet struck. For natural disasters, this period of time may be very short and give little opportunity for preparation. For a crisis, the incentive to try to contain the situation may result in a period of denial that a problem exists. This can be a psychological denial, where those responsible refuse to acknowledge the risk even to themselves or a more calculated denial, where the problem is denied to the outside world in an attempt to preserve markets, esteem or resources. However, for both crises and disasters there needs to be a "triggering event" that marks the beginning of this prodromal stage.

For FMD the triggering event was the first suspected, and then subsequently confirmed case of the disease (the process of confirmation can take between 24 and 48 hours), yet although the implications of one case of FMD are serious, reports of the disease did not appear in the media until the number had increased significantly and 
some days had passed. Thus, unlike for a catastrophic event like a flood, earthquake, explosion, or acts of terrorism, the potential for denial of the existence of a problem was greater, as the full extent of the problem was not discovered, and indeed had not yet occurred.

The advantage of this extended Prodromal phase was the increased time available to develop a strategy to limit the spread and impact of the disease. Here the distinction between the aims of the farming community and the tourism industry is revealed. The initial reports of the disease focused on the implications for farmers, how this would threaten the price of UK meat products and the likely reaction of destination markets. As is typical of any national event there was a large amount of disagreement as to what the "correct" course of action should be. Within the farming community there was also disagreement as to whether vaccination or the policy of culling would be the most beneficial. However, the National Farmers Union (NFU) opposed the vaccination of healthy livestock as any such action would destroy the market value of the animals, although it would prevent the spread of the disease. Given the limited choices, the NFU instead favoured burning infected cattle and limiting the movement of animals and people throughout rural areas.

For the tourism industry, none of its infrastructure had been threatened or damaged, FMD is generally not contagious to humans and the disease causes no impact on the visual landscape. Yet the policy of slaughtering and then burning infected and suspected animals damaged the essential intangible quality that is the appeal and image of a destination. Thus, the disaster for the tourism industry was not the disease itself, but the actions taken to eradicate the farming crisis and the media images 
associated with these actions. There was also a perception, particularly from the North American market, according to ETC and BTA briefing reports, that the whole of the UK was effectively closed due to this disease and that it was contagious to humans.

This is perhaps a good example of the 'ripple effect' (Heath, 1998) which can exacerbate the magnitude of crises through ineffective crisis management. Managing the public perception during a crisis situation is critical. As Heath (1998:26) notes "crisis management is as much about dealing with human perceptions about the crisis and the management of a crisis as it is about physically resolving the crisis situation." However, difficulties arise in managing the media as it is unlikely that there will be a time delay between the start of any crisis and media coverage (Ashcroft, 1997). Both Burnett (1998) and Marra (1998) note that effective crisis communication strategies are required as part of a strategic approach to dealing with crisis situations. Marra (1998:461) notes that poor communication strategies can often make the crisis worse as a deluge of questions is often asked from a wide range of stakeholders including reporters, employees, stockholders, government officials and public residents.

Faulkner (2001: 142) argues, "the effectiveness with which the tourism industry in a disaster area handles a crisis, and the degree to which it is prepared for it, has a bearing on how quickly services are restored to normal". The tourism industry, like all other industries was not prepared for FMD, yet the ability of the industry to be prepared in a way that can protect its industry is determined by the relative power of the tourism industry compared to other industries, such as the farming industry. The NFU is a strong and well-organised lobbying body, while the fragmented nature of the 
tourism industry found difficulty in speaking with one voice that could be heard (Cotton, 2001).

A $26 \%$ growth in tourism revenue occurred over the year to 2001 with tourism contributing $7 \%$ of the workforce in rural areas, compared with a $21 \%$ decline in agricultural revenue contributing only $1.5 \%$ of the workforce (ETC, 2001b). Tourism can be seen to be one of the key drivers of the British economy and supports around 1.7 million jobs, with 1 in 5 of all new jobs created in the tourist industry (Star UK Statistics, 2001). Yet FMD was a farming disease that threatens the very resources of the tourism industry. The long prodromal stage of the disaster and the lack of previous planning ensured that this debate was held during the disaster and served to create tensions between elements of all areas of the UK.

Typical of the division is the position statement released by the British Tourist Authority (BTA) amidst the disaster, stating, "tourism has a responsibility to support farmers and help eradicate foot and mouth disease, but its primary concern is to safeguard the long term interests of the tourism industry, especially the small and medium sized businesses who are most affected by the outbreak and are characteristic of rural tourism" (BTA, 2001). While the prodromal stage of FMD was longer than for other disasters and allowed more time for considering responses, there is little doubt that organisations will be afforded sufficient time to think widely and to take any steps other than those that affect their primary responsibilities. However, the primary responsibilities of the NFU are to farmers and in the absence of a predetermined disaster management plan, the NFU were able to influence government policy in a way that favoured farmers, to the detriment of the tourism industry. Thus, 
the policy of slaughter, incineration and denied access continued while the policy of vaccination was continually proposed and subsequently rejected.

Thus, one can question in a disaster like FMD, where different sections of society are affected differently, then whose disaster is it, and who should the response measures be aimed at aiding? Holder (1992) cites contention among the public and private sector in their respective roles in the tourism industry and argues that the partnership can be typified allegorically by provision of the locomotive by the private sector, while the public sector should be held responsible for laying the rails on which the train proceeds. Holder continues that if the track is correctly laid and the points well managed then the train will proceed at speed and in safety, yet he concludes that "unfortunately there are cases where governments have been neglecting the care of the rails, while showing an unnatural fascination for occupying the driver's seat of the train" (pp160). However, to continue the analogy, the FMD express often appeared to be without a driver and when any direction was provided it was for the benefit of a small number of passengers only.

The Cheltenham Festival typifies the conflict between farming and tourism during this stage of the disease. The rural location of the Festival meant that its origins lay in the development of the countryside through farming, and despite changes to the Festival, had been regarded as a manifestation of the lives of those from the countryside. The decision by the managing director at Cheltenham to continue with the Festival against farming advice was seen as a sign of disloyalty, preferring to ally the Festival instead with the tourism and leisure industries. Faulkner (2001:139) encapsulates this division, "Community responses to disasters, both during the 
emergency and afterwards in the recovery period, involve many different organisations. In this situation, it is not uncommon for competition and rivalry among these organisations to become a major impediment to both co-ordination and the ability of organisations to respond effectively". The need for a united approach to the resolution of a disaster is almost an axiom, yet the length of the prodromal period of the FMD disaster served instead to widen and create divisions rather than the pressure of limited time creating the opportunity to work together and overcome institutional or sectoral barriers.

\section{Emergency}

Faulkner \& Vikulov (2001) demonstrate the effect on the Australian town of Katherine once the flood struck on the night of the $25^{\text {th }}$ January 1998. The emergency stage of the disaster lasted until the rain stopped and river levels began to reduce, which occurred within 24 hours. However, for FMD, the long prodromal period merged with an emergency period that could be measured in months and where the effects were not ubiquitous when the disease did strike. One implication of the different timeframe is the role of the media throughout the disease. Rather than reporting on a single catastrophic event, and then turning to the clean-up operation and implications, the media was able to play an investigative role as the size of the problem gradually became revealed and the response from other countries was also demonstrated. Harr (1994 cited in Faulkner, 2001) explains that 20\% of emergency staff's time can be spent in supplying the message and controlling and limiting the damage done by media reporting of the event. For FMD, the story topped news programmes and newspapers for months, yet in addition to time spent providing the media with information, the media undoubtedly influenced the way the disaster was 
managed, as every step could be scrutinised and presented to the public before decisions were taken.

A further consequence of the drawn out emergency stage of FMD was the encroaching deadline for the government to announce a general election. The government held a strong lead over political rivals in the polls and had made little secret of its desire to face a spring election. However, the images of burning cows saturating news coverage meant an early election was impossible unless the disease could be eradicated without risking the rural vote that was heavily influenced by the farmers. Yet, the crisis/disaster conflict reflects the multi-sectoral nature of industry in rural areas, and there was disagreement over how the emergency stage should be handled. In addition, some rural regions remained unaffected throughout and so varied in their beliefs as to what should be done to contain the disease. In addition, there remained a suspicion throughout FMD that, in an increasingly urbanised Britain, this was a rural problem, following on from Bovine Spongiform Ecephalopathy $(\mathrm{BSE})^{1}$, debates over fox-hunting and the right to roam legislation. Such sentiments expressed via the media further demonstrated the split FMD was causing as to how to manage a current and continuing emergency.

\section{Intermediate}

The intermediate phase is the point where the short-term needs of people have been addressed and the main focus of activity is to restore services and the community to normal. However, "normal" may not be defined as the pre-disaster position, as this may be neither possible, nor desirable. There were no tourism resources damaged by

\footnotetext{
${ }^{1}$ BSE is more commonly known as "mad cow disease" and is linked with the fatal form of the human disease Variant Creutzfeldt-Jakob Disease (vCJD)
} 
FMD to be repaired and the blackened image of the UK could not be repaired until the disease had been defeated, despite many areas of the UK having never been affected by the disease. Thus, the nature of the disaster meant that there was no "turning point" when a town was re-opened, or a building restored or re-built, instead areas of the country gradually tried to persuade visitors that it was safe to visit, while other areas of the UK continued to suffer with new outbreaks of the disease. Such a scenario led to calls from some sectors of the tourism industry to proceed with advertising campaigns encouraging visitors to the countryside, while for others, such confidence-building campaigns were mis-placed until the problem had universally been removed.

The ETC was given $£ 3.8 \mathrm{~m}$ to promote tourism to a domestic audience in April 2001, which was spent on specific market campaigns, coupled with developing websites to inform potential visitors of where was safe to visit. The ETC calculated that this financial aid generated 766,000 additional visits and produced a return on investment of $£ 27$ for each $£ 1$ spent (ETC, 2001a). In May, a further $£ 12 \mathrm{~m}$ was given to the BTA for international marketing, while no further finance was available for the ETC and the domestic market (ETC, 2001a). Some industry representatives questioned the speed of the marketing finance and suggested that it was far too little too late (Cotton, 2001).

For the Festival, the opportunity to re-stage the event at a later date in the year had disappeared, and there was little intermediate action that could be taken to repair the damage of the disease. Indeed, the main intermediate steps were providing refunds to 
customers who had booked tickets in advance and trying to re-claim deposits lodged with suppliers for the cancelled Festival.

\section{Long-term (Recovery)}

This phase is a continuation of the intermediate phase and saw Cheltenham move to repair bridges with main customer groups, suppliers and other stakeholders after the cancellation of the Festival. Around 5000 customers from Ireland attend the Festival each year, as well as a large number who live in England, giving the Festival its famed Irish feel. However, Managing Director Edward Gillespie said “...the Irish were pretty upset with us in February and March when we originally said we were going ahead with the Festival and the Irish were not able to come, they got very upset with us. It was like us going ahead with a party, but our chief guest couldn't come. They got very upset with us". The number of cancellations has led one of the main airlines serving the route from Ireland to institute a policy requiring full-payment 10 weeks in advance of travel, while many of the hotels in Cheltenham town had refused to return deposits, creating much ill-feeling. This coupled with a general rise in the stature of hunt racing in Ireland and a strengthening of the British pound left the vaulted position of the Festival in a vulnerable position to a challenge from a rival Irish racecourse. The long term recovery of the festival is contingent upon relations with the principal customer group being repaired and the Irish being willing to travel back to Cheltenham.

\section{Resolution}

The final phase of a disaster is the return to routine, or movement to an improved position based on reflection. Klein (2000) uses the introduction of the first company 
safety laws as a result of a fire that killed workers in the Triangle Shirtwaist company in New York in 1911 to illustrate the benefit that can accrue from disaster. Similar to crisis management approaches discussed previously, Faulkner (2001), referring to educational theory, describes this as the potential from the events for single loop, or double loop learning. Kolb's (1984) framework identified how the process of an experience leads to reflection that produces a proposed solution, which is ultimately tested and so leads to a new experience and a new round of solutions (illustrated in figure 6). Double loop learning requires a paradigmatic shift as a result of the experience and so emergent knowledge is produced and ultimately new understanding is derived (figure 7). The distinction between a crisis and a disaster means that those who precipitate a crisis are better placed to reflect on mistakes that caused the problems and institute a paradigmatic shift in thinking. Conversely, and as evidenced by history, those who suffer the effects of a disaster react to events and are contained to single loop actions, if not single loop thinking, unless a larger body can enforce the necessary changes to prevent the events repeating themselves.

Figure 6: Single Loop Learning

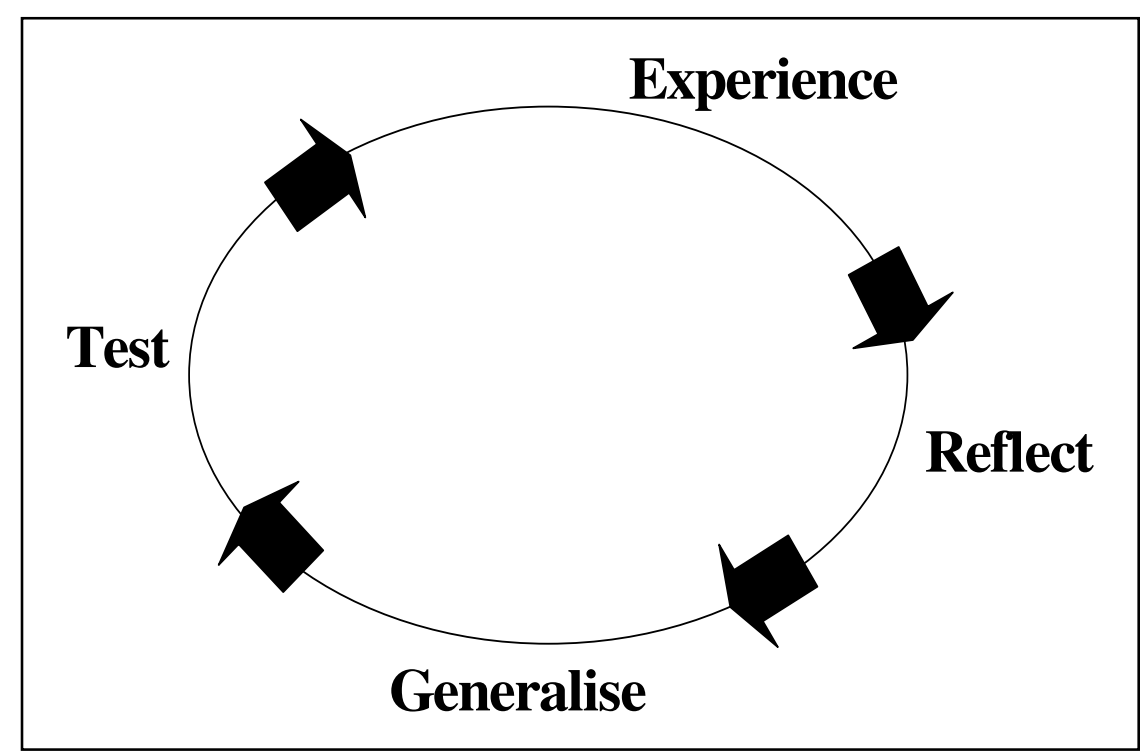

Source: Kolb (1984) 
Figure 7 Double Loop Learning.

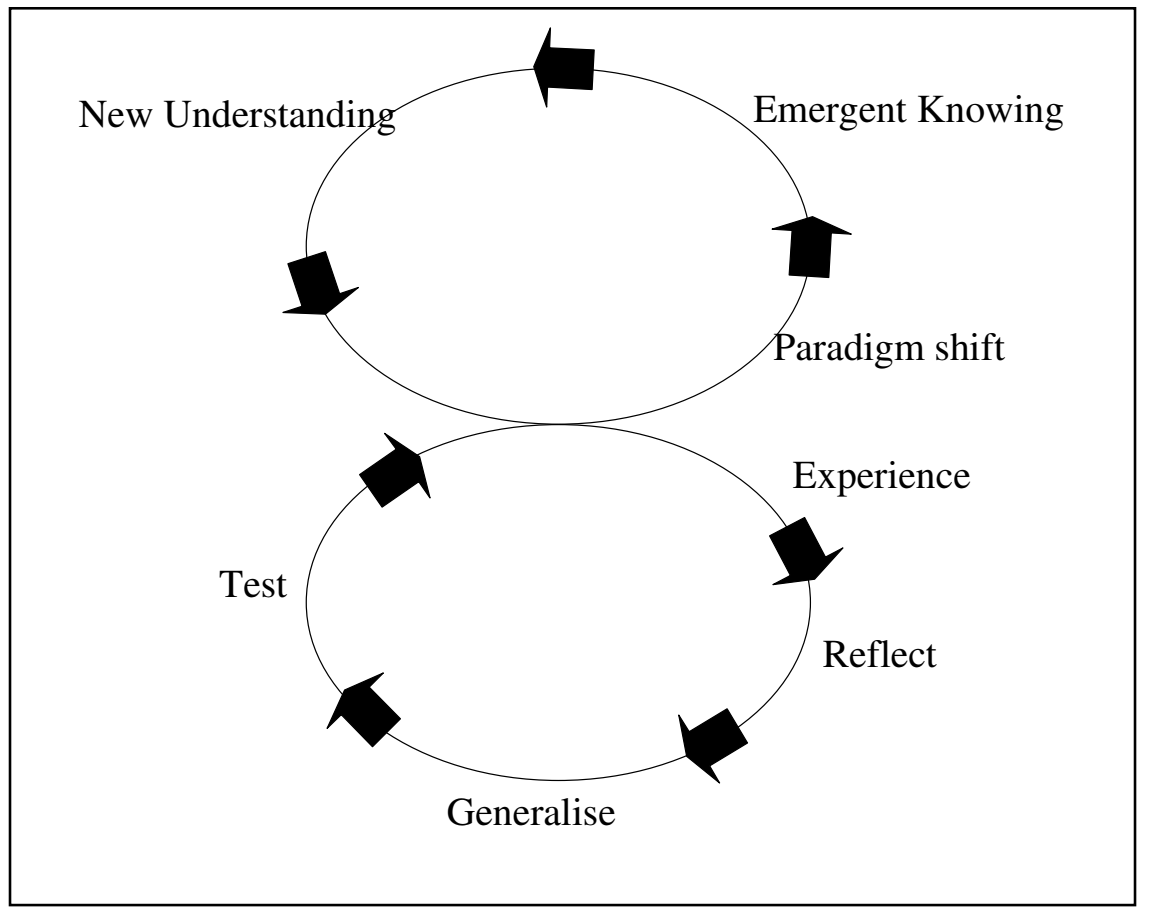

Source: Kolb (1984)

To this end, the larger body forcing change has been the national government and the principal change has been the creation of a new government ministry, the Department for the Environment, Food and Rural Affairs (DEFRA) from the ashes of the old Ministry for Agriculture, Fisheries and Food. This move illustrates two central themes to this paper well. Firstly, it is indicative of the relative power of the farming industry and the tourism industry that the department for tourism does not sit within this newly formed ministry, but instead remains within the Department for Culture, Media and Sport (DCMS). While secondly, the move demonstrates a lack of understanding by the government about the tourism industry. The much heralded claim of the Labour government has been to produce "joined-up government", yet the exclusion of the representatives of the tourism industry from the new ministry for rural affairs can do little to promote tourism's influence over future disaster preparations, or more positively, over the continued changes taking place to the economic and social fabric of rural areas, of which tourism is a major contributor. 
The government also introduced plans for a crisis management unit within the national government staffed by 100 civil servants which will report to the prime minister through the cabinet secretary. The unit has been tasked with 'scanning the horizon' to provide an early warning system of looming disasters. Once a crisis develops, the unit will ensure that government departments co-ordinate their responses more effectively both within government and in communicating to the outside world. However, the appointment of a press officer to run the unit suggests that the government is perhaps more concerned with managing crisis communication to the general public.

Yet, as a result of FMD, the tourism industry has benefited from a heightened profile and a wider recognition of its contribution to the economy as a whole and specifically to the rural economy. To try to capitalise on this elevation, the tourism industry has formed a Tourism Alliance "to enable the tourism industry to speak with a united, cohesive voice" (Travelmole, 2001a), headed by the Director-General of the Confederation of British Industry (CBI). Such a chair can do much to ensure tourism does not become excluded, or sidelined from the planning for, or management of future disasters. However, if power does not shift to the tourism industry, then any preparations become a cosmetic exercise and the notion of disaster planning and management in tourism becomes devalued.

For Cheltenham, FMD has meant a valuable revision of its relation with its customers and stakeholders. The disaster has forced a recognition that there had been some complacency with regard to the value of customers from Ireland and a determination 
not to take them for granted in the future. Similarly, the 6500 members of Cheltenham were not entitled to a refund on their membership because of the cancellation of one particular racing meet during the year, even though the Festival represents the main attraction of membership. This caused great upset amongst some members and the managing director concedes the problems arose in describing a policy that was not well stated originally and “...if you haven't had a reverse in 55 years, you get out of the habit of how to handle it". However, as a result of the disaster "...we will better state it (the policy) so that people know at the point of engagement what the deal is...it is a very good example of how we have taken them for granted and therefore we haven't managed it well and so we now have a whole new re-design of how we are going to engage with our members" (Gillespie, 2001).

Similarly, the cancellation of the Festival meant local hoteliers, restaurateurs and others dependent on the 3 day meet were forced to re-evaluate their relationship with the racecourse. There is evidence that suppliers have profited from FMD by being refunded after the decision to cancel, and then not passing this refund on to those who would supply the suppliers. Such practices have led to a revision of relationships and a tightening of the procedures for engagement with suppliers.

\section{Conclusion: A Critique of the Disaster Framework}

FMD was a very different type of disaster from the Katherine floods, to which Faulkner \& Vikulov (2001) apply the Faulkner (2001) disaster management framework. FMD was a disaster with broad temporal and spatial boundaries, while the Katherine floods were very concentrated in both time and space. Conversely, the tourism industry of Katherine, despite high and low seasons, is continuous and 
occupies an area sufficient to accommodate 11,000 residents whereas the Cheltenham Festival occurs over three days in March and is contained within an area the size of a racecourse. Further, FMD was a complex disaster as the prodromal, emergency and recovery stages were all happening simultaneously for large periods of time, not just for different locations, but for different industrial sectors of the same location, and in some cases within the same organisation. As a result, the optimistic aim of reflection producing healing never materialised, instead deep divisions within the countryside have emerged, and worsened relations between urban and rural areas. Thus, while Faulkner's (2001) model does serve to identify stages to the disaster, they are not as clearly discernable as for the Katherine floods. This may be due to the evolving nature of the disaster or the role of the media, but may also be as a result of its application to an organisation rather than a discrete destination.

Faulkner (2001:136) suggests that "the increased volume of global tourism activity has combined with the attractiveness of high-risk exotic destinations to expose tourists to greater levels of risk". Yet, the Cheltenham Festival occupies just three days in the annual sporting calendar and takes place in a delightful, yet far from exotic, rural area to the west of England. The rarity of such an event being impacted upon by a disaster meant that pre-disaster planning was almost non-existent and later found to be unhelpful. Subsequent stages of the disaster were influenced largely by the power position of the tourism industry vis-a-vis the farming industry and meant that the prodromal, emergency and recovery stages were concerned with responding to the disaster that became the farming industry's suggestions of how to react to the FMD crisis, which in turn led to a tourism disaster. Little proactive strategies 
planning were made in relation to a tourism disaster in the UK and managers had to deal with the crisis in the best way they could.

Thus, the framework can be seen as an analytical tool of what happened, but would have limited value in enabling event managers to steer a pre-determined course through such an unlikely, yet catastrophic event. However, the case of FMD has illustrated how a crisis from one industry (farming) can impact upon another (tourism), and how this can be exacerbated through the 'ripple effect' and a lack of crisis management planning and preparation. The nature of the tourism industry dictates that the industry should be better prepared for dealing with crises, disasters and fluctuations of demand. Yet in the case of the UK and FMD this preparation was not evident, and so the disaster was not dealt with as effectively or efficiently as it should have been. It is hoped that this paper has contributed in some way to providing lessons for tourism destination managers and organisations through the case of the FMD in the UK.

\section{Postscript}

A survey of domestic tourism in the UK showed that as a result of FMD spending for the first 6 months of 2001 had declined by $6 \%$, when compared with the first 6 months of 2000. This had produced losses of $£ 1$.4billion from January to June 2001 (Travelmole, 2002), yet during this period larger towns and cities saw an increased level of businesses from domestic tourism as they were perceived to be safer places to visit. Domestic tourism in the UK contributes $£ 4$ out of every $£ 5$ earned through tourism, equalling £2billion more revenue earned through five times as many trips as made by overseas visitors. However, international visitors were also keen to remain 
in urban areas, denying the countryside its share of the $£ 12.5$ billion international visitors spend in the UK (BTA, 2001).

The events of September $11^{\text {th }} 2001$ in New York, Washington and Pennsylvania had a severe impact on tourism in the UK. Figures for air traffic from the North Atlantic show a $31.3 \%$ decline for October and $26 \%$ decline for November (Travelmole, 2001a), the same large cities and towns that had benefited from FMD when perceived as safer places to visit, now faced a significant decline in visitors as they were seen as potential targets from terrorism. The increased risk of overseas travel resulted in evidence of people switching to holidays in the UK rather than travel overseas. Research conducted by the ETC in October 2001 revealed $15 \%$ of respondents had cancelled their trip, either domestic or international, $25 \%$ had postponed, $48 \%$ decided not to make any plans until the situation was more clear, yet $19 \%$ of those contacted had switched to holidaying in the UK rather than abroad (Travelmole, 2001b). The main beneficiaries of this decision were rural destinations, which were once again perceived to be safe areas to holiday.

Within the course of 8 months the rural tourism industry had suffered huge losses from FMD and then benefited from growth as domestic tourism increased and diverted to the countryside. Such a course of events illustrates the vulnerability of the tourism industry to disasters, but demonstrates the potential for positive change to emerge. However, the extent of negative or positive impact is largely beyond the control of the tourism industry. Both FMD and the terrorism on September $11^{\text {th }} 2001$ could not have been influenced by the tourism industry, only responded to, while both events were entirely unpredictable. Despite the valuable attempts of Faulkner (2001) to introduce the topic of disaster management to tourism, the case of FMD and 
September $11^{\text {th }} 2001$ perhaps accounts for the lack of preparedness amongst the industry and literature covering adequate responses to disasters. 


\section{References}

Ashcroft, R (1997) Crisis management: Public relations. Journal of Managerial Psychology 12 (5), 325-332.

BTA (2001) Foot and Mouth Disease Briefing, $3^{\text {rd }}$ April.

Burnett, J. (1998). A Strategic Approach to Managing a Crisis. Public Relations Review 24 (4), 475-488.

Cook, E (1999) Countryside in Crisis. The Independent, London, August 29th

Coombs, T. (1999) Ongoing Crisis Communication: Planning, Managing and Responding. Thousand Oakes, CA: Sage.

Cotton, B. (2001). Foot and Mouth: The Lessons We Must Learn. Tourism: Journal of the Tourism Society Autumn, 110, 5.

Darling, J., Hannu, O. \& Raimo, N. (1996) Crisis Management in International

Business: A Case Situation in Decision Making Concerning Trade with Russia. The Finnish Journal of Business Economics Vol. 4.

English Tourism Council (2001a) Press Briefing, ETC, London, 25 ${ }^{\text {th }}$ July.

English Tourism Council (2001b). ETC http://www.englishtourism.org.uk/

21 December 2001. 
Faulkner, B (2001) Towards and framework for tourism disaster management. Tourism Management 22 (2), 135-147.

Faulkner, B. \& Vikulov, S (2001) Katherine, washed out one day, back on track the next: A post mortem of a tourism disaster. Tourism Management 22 (4), 331-344.

Fink, S (1984) Crisis Management: Planning for the Inevitable. New York: American Association of Management.

Gillespie, E (2001) Managing Director of the Cheltenham Horseracing Association. Personal Interview. $20^{\text {th }}$ August.

Heath, R (1998) Crisis management for managers and executives. London: Financial Times Management.

Holder, J. 1992. The Need for Public - Private Sector Co-operation in Tourism. Tourism Management, June, pp157-162.

Kash, T. \& Darling, J (1998) Crisis management: Prevention, diagnosis and intervention. Leadership and Organisation Development Journal 15 (4), 179-186.

Klein, N (2000) No Logo. London: Flamingo

Kolb, D (1984) Experiential Learning. New Jersey: Prentice-Hall. 
Marra, F. (1998) Crisis Communication Plans: Poor Predictors of Excellent Crisis

Public Relations. Public Relations Review 24 (4), 461-474.

Pauchant, T. \& Mitroff, I. (1992) Transforming the Crisis Prone Organization. San Francisco, CA: Jossey-Bass Publishers.

Roberts, V (1994) Flood management: Bradford paper. Disaster Prevention and Management 3 (3), 44-60.

Richardson, B. (1994) Crisis Management and Management Strategy - Time to "Loop the Loop"? Disaster Prevention and Management 3 (3), 59-80.

Richardson, B. (1995) Paradox Management for Crisis Avoidance. Management Decision 33 (1), 5-18.

Travelmole (2001a) BAA November passenger traffic down.

http://www.travelmole.com $13^{\text {th }}$ December.

Travelmole (2001b) ETC: The impact of $11^{\text {th }}$ September on English Tourism.

http://www.travelmole.com $12^{\text {th }}$ November.

Travelmole (2002) ETC launches countryside campaign.

http://www.travelmole.com $28^{\text {th }}$ January. 